\begin{tabular}{|l|lll|}
\hline 2 & Layout: T3 Standard Unicode & Book ID: 318043_1_En & Book ISBN: 978-3-319-08996-6 \\
Chapter No.: 26 & Date: 21-11-2014 & Time: 6:57 pm & Page: 1/9 \\
\hline
\end{tabular}

\title{
Megyer Hill: Old Millstone Quarry
}

\author{
J. Szepesi - Zs. Ésik
}

\begin{abstract}
In the Sárospatak region of the Tokaj Mountains, Northeast-Hungary, thick Badenian ash flow deposits accumulated in submarine settings and later uplifted and suffered intensive hydrothermal alterations. The semi-circular range of Megyer and Király Hills was formed by differential weathering and selective erosion of rocks in the intensely altered and mineralized zones. The exploitation of raw materials has a long history in the region. The secondarily hardened rocks provided building materials for the surrounding settlements; the pottery was supported by clay minerals. The intensely silicified pyroclastic rocks were used as millstones as early as the 15th century. The legendary French-style millstones won the FirstOrder Medal of the 1862 World Expo in London The picturesque lake in the abandoned quarry was selected as Hungary's most beautiful natural attraction in 2011.
\end{abstract}

Keywords

Ash-flow deposit - Submarine volcanism - Silicification - Millstone quarrying - Cultural values • Tokaj-Hegyalja

\subsection{Introduction}

Tokaj-Hegyalja, the foothill of the Tokaj Mountains, is built up of ignimbrite sheets around stratovolcanic and acid extrusive centres (Fig. 26.1). The south-facing slopes on rhyolite tuffs coupled with soils and microclimate defined a special viticulture. The world's first closed wine region (since 1737) was declared a UNESCO World Heritage site, the Tokaj Wine Region Historical Cultural Landscape, in 2002. In addition to rows of cellars, the quarries (e.g. Mád, Bodrogkeresztúr, Sárospatak-Fig. 26.1) producing millstones, building and decorative stones also determined the landscape character. With its millstones of unique quality Sárospatak acquired a European reputation.

J. Szepesi $(\bowtie)$

MTA-ELTE Volcanology Research Group, Hungarian Academy of Sciences, Pázmány Péter sétány 1/C, 1117 Budapest, Hungary e-mail: szepeja@gmail.com

\subsection{Volcanism in the Tokaj Mountains}

Volcanism in the Pannonian (Carpathian) Region was active since the early Miocene through various phases in variable geotectonic and magmatic settings (see Chap. 1). The heterogeneity of the mantle source and crustal differentiation is manifested uniquely in the same amounts of rhyolitic and andesitic rocks deriving from the Badenian-SarmatianPannonian period (15-9.4 Ma-Pécskay et al. 1995). The rare olivine basalt was emplaced as a final effusion. The Proterozoic to Mesozoic metamorphic and carbonate basement (Fig. 26.2) was subsided to form a north-south oriented graben-like structure hosting the volcanic sequences of the Tokaj Mountains (Gyarmati 1977). Extension processes were accompanied by basement subsidence and marine transgression, so the thick Badenian acidic (e.g. Megyer Hill ash flow tuffs) and intermediate formation accumulated in submarine environment but the archipelagic nature became prevalent with the thickened volcanic sequence in the Sarmatian (Fig. 26.3). 


\begin{tabular}{|l|lll|}
\hline Layout: T3 Standard Unicode & Book ID: 318043_1_En & Book ISBN: 978-3-319-08996-6 \\
Chapter No.: 26 & Date: 21-11-2014 & Time: 6:57 pm & Page: 2/9 \\
\hline
\end{tabular}

Fig. 26.1 Panorama of the lake of Megyer Hill (photo by János Szepesi)

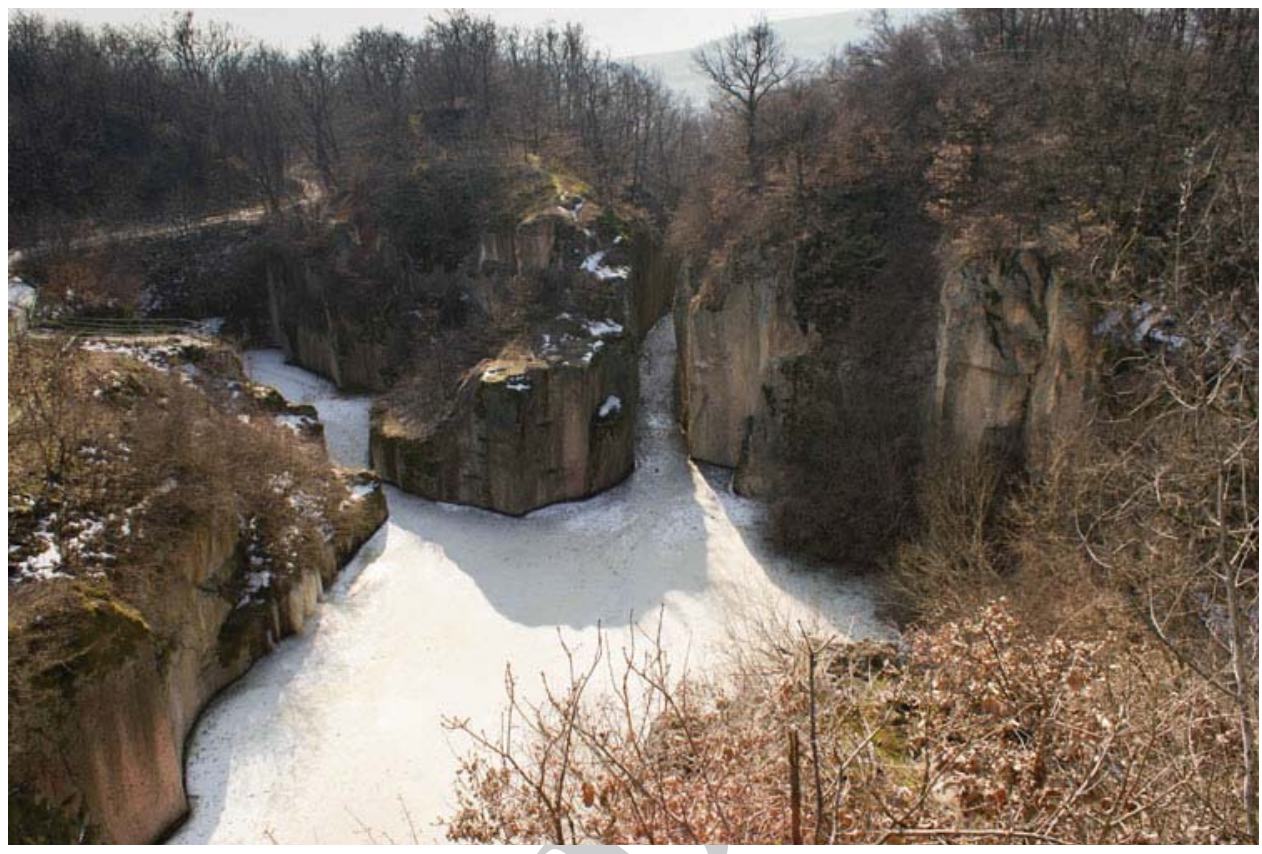

Based on radiometric ages, the andesitic-dacitic stratovolcanic centres operated synchronously with pyroclastic flows and plinian eruptions. With the reduction of explosion energy the formation of thick tuff horizons was followed by extrusion of coherent lavas (perlites, rhyolites), uniquely diverse in the Carpathian Volcanic Chain.

Postvolcanic activity reached its peak in the SarmatianPannonian and ended in the Pleistocene. The thermal circulation of exogenic water along fractures was often promoted by the higher porosity of ash flows rich in pumice. Erosion revealed the mineralized zones (Pécskay and Molnár 2002). The deepest, K-metasomatic deposits are well known from the gold-silver bearing quartz veins (Telkibánya, Rudabányácska). The Király-Megyer Hill range is one of the best examples of the surrounding alunitic-kaolinitic zone.

The volcanism and hydrothermal activity generated raw materials, mainly non-metallic mineral resources, 13 special raw materials (including quartzite, kaolinite, bentonite, perlite) at of 47 known occurrences (Mátyás 2005).

\subsection{Geology of the Király-Megyer Hill Range}

The Király-Megyer Hill range of $9 \mathrm{~km}^{2}$ area along the northeastern boundary of the Tokaj Mountains, north of Sárospatak form a semi-circular range around a local basin opening to the south. The effective postvolcanic alterations result from the regional morphological-tectonic pattern. The tectonic lines of the basement were renewed by younger extensional processes. The main structural lines are north to south directed.
Sárospatak and its environs was one of the most frequent areas of geological research in the last 200 years. The city was known for millstone manufacturing, ceramics and glass production in the middle ages but geological knowledge only began to accumulate in the 19th century. After sporadic observations the first comprehensive works were published by Szabó (1867), who classified acid pyroclasts by their utilization (millstone, powder tuffs) and recognized the Badenian age of the silicified tuff of Megyer Hill based on mollusc fauna. Detailed raw material exploration accelerated after World War II. The geological, tectonical and geothermal conditions and the non-metallic resources (bentonite, kaolin) were characterized by Frits $(1959,1964)$. The cinnabar, as a characteristic mineral of zonal hydrothermal alteration was identified by Kulcsár (1968) based on the analogy of the Beregovo Hills in Ukrainian Transcarpathia. The comparative investigation of postvolcanic mineral paragenesis with the genetic relationships of the hydrothermal zonation was focused on the alunite resources of Király Hill (Mátyás 1969, 1977). The issue was re-investigated and clarified by new methodologies ( $\mathrm{K}-\mathrm{Ar}$, fluid inclusion, isotope studies-Molnár 1993; Pécskay and Molnár 2002).

The Király-Megyer-Botkő group is one of the many hydrothermal centres aligned to the regional tectonic patterns. The Mesozoic basement has influenced recent and paleogeothermal activities. Although the presence of limestone xenoliths in the ash flow tuff had indicated a Triassic basement before deep drillings began, it was still surprising that a borehole reached the Mesozoic at only $225 \mathrm{~m}$ depth (ca $90 \mathrm{~m}$ above sea level) and the karst cavities supplied $40{ }^{\circ} \mathrm{C}$ thermal water with $2 \mathrm{~m}^{3} \mathrm{~min}^{-1}$ discharge. 


\begin{tabular}{|l|lll|}
\hline Layout: T3 Standard Unicode & Book ID: 318043_1_En & Book ISBN: 978-3-319-08996-6 \\
Chapter No.: 26 & Date: 21-11-2014 & Time: 6:57 pm & Page: 3/9 \\
\hline
\end{tabular}

Fig. 26.2 Geological map of the Tokaj-mountains with the main rhyolite tuff and millstone quarries (modified after a volcanological sketch by Gyarmati 1977)

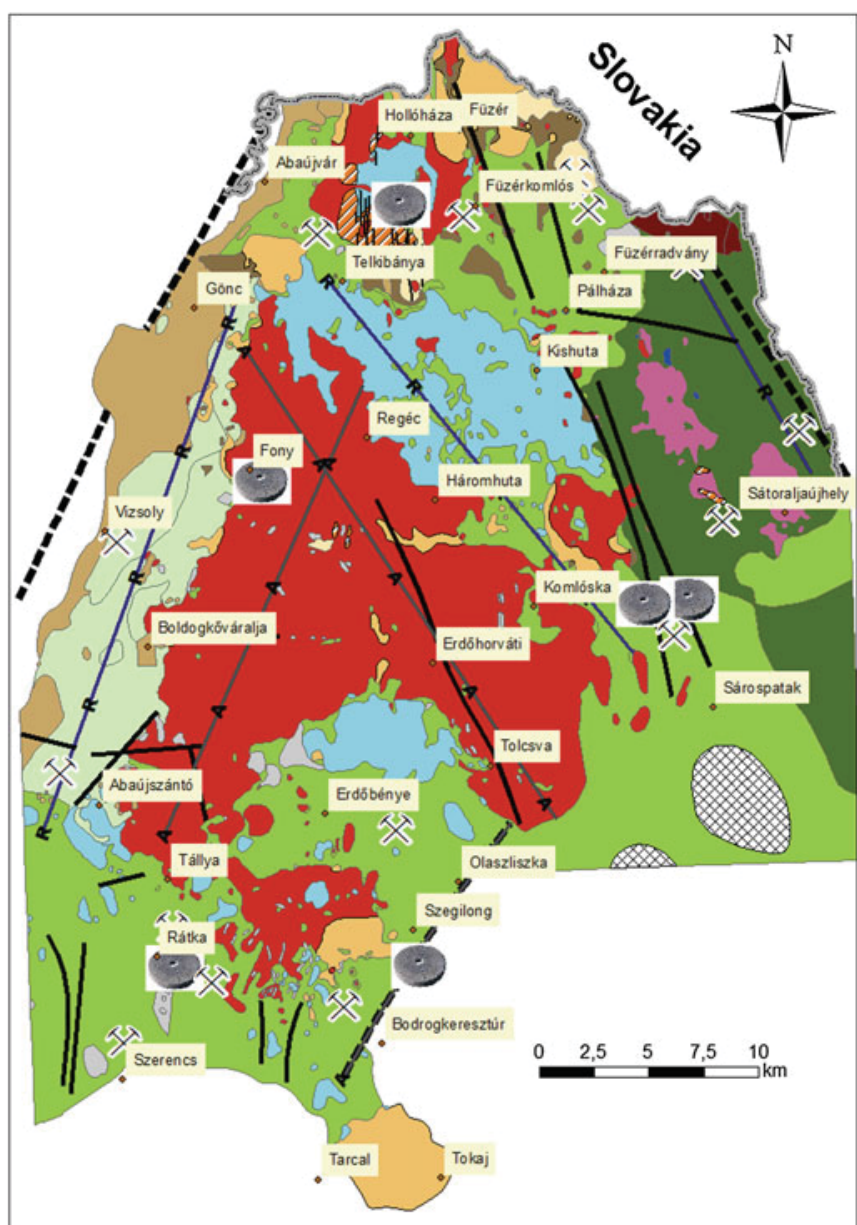

Sarmatian-Pannonian series

basalt flows

hydrothermal sedimentary sequence

clay, sand, marl, tuffite

younger ash flow tuffs

VIIA alkaline metasomatized intrusions

rhyolite lava domes

pyroclastic fall, flow and reworked deposits

rhyodacite lava domes

dacite lava domes and intrusions

andesite lava flows and intrusions

\section{Badenian series and basement}

clay

rhyolite domes

dacite lava domes

pyroclastic flow and reworked deposits

schist, sandstone, porphyrite

X rhyolite tuff quarry

millstone manufacture

structural faults
The onset of the volcanism was accompanied by a general transgression and the first rhyodacitic submarine ash flow series are intercalated with older basement debris. On the eroded surface of Mesozoic limestone tuffaceous conglomerate formed. The welded parts and smaller eroded rhyolite lava dome necks emerged as small islands. Under similar paleoenvironmental conditions volcanism turned to rhyolitic character to produce the predominant millstonerhyolite tuff unit deposited in a submarine caldera but subordinately bedded ash fall tuff from plinian eruptions (at Király Hill) is also present. The abundance of angular and variable rounded pumice clasts defines a lithic (perlitic lapilli) pumice breccia facies (Fig. 26.4). The absence of the wave-generated bedforms are consistent with a below-wavebase environment, also supported by molluscs (Chlamys, Cardium, Isocardia-Szabó 1867; Kulcsár 1968). Large quartz phenocrystals, less common plagioclase and rare biotite are typical for Badenian pyroclast series. 


\begin{tabular}{|l|lll|}
\hline 2 & Layout: T3 Standard Unicode & Book ID: 318043_1_En & Book ISBN: 978-3-319-08996-6 \\
Chapter No.: 26 & Date: 21-11-2014 & Time: 6:57 pm & Page: 4/9 \\
\hline
\end{tabular}

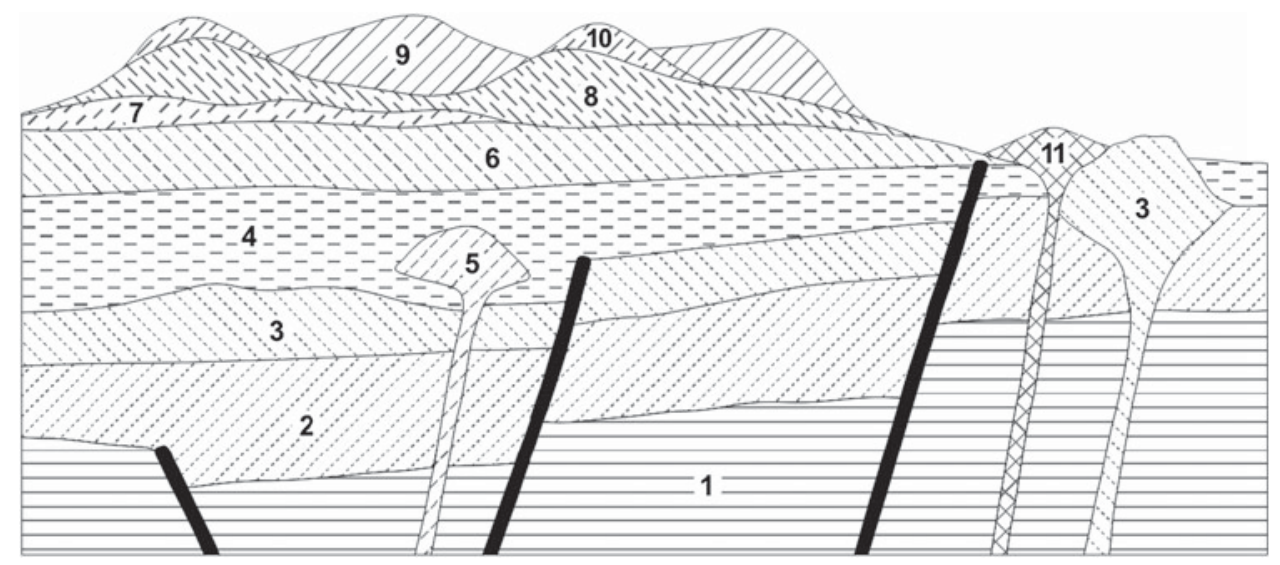

Fig. 26.3 Schematic spatial and temporal relationships of geological formations in the Tokaj Mountains (Gyarmati and Szepesi 2007). 1 Prevolcanic basement; 2 upper Badenian pyroclasts with intercalated marine sediments (15-14 Ma); 3 upper Badenian submarine and subvolcanic intermedier volcanites $(15-13 \mathrm{Ma}) ; 4$ lower Sarmatian pyroclasts with brackish sedimentation (13-11 millió év); 5 lower
Sarmatian rhyolite lavadomes and flows; 6 Sarmatian andesitic and dacitic volcanites; 7 intercalated pyroclasts; 8, Upper Sarmatian intermediate lava flows (11-10 Ma); 9, Youngest (Pannonian) rhyolite and rhyodacite (10 Ma); 10, Youngest intermediate lava flows (10-9 Ma); 11, Olivine basalt (9.4 Ma)
Fig. 26.4 The pumice breccia character of the ash flow tuff in the wall of the wagon road (photo by János Szepesi)
Its thickness suggests that the sequence was generated by magmatic volatile-driven explosions. The subaerial pyroclastic flows crossed the shoreline, and transformed into eruption-fed subaqueous volcaniclastic density currents. The curved pumice clasts probably rounded during the transportation.

At the end of Badenian and Early Sarmatian a further marine transgression occurred and rhyolite tuff and tuffite accumulation and reworking as well as shallow-water clay and sand sedimentation took place. The Lower Sarmatian series deposited in lagoons. Thinning layers are found at the foot of Király-Megyer Hill group (Cinegés quarry, Nagybotkö) and in boreholes. The accumulation was fed by the material of plinian clouds, reworking of former Badenian series coupled with hydrothermal activity. The diverse series consisted of alternating tuffaceous clays, pumice breccia and limnic quartzite layers (I Perlaki 1989).

The strongest hydrothermal activity occurred along the Király and Megyer Hills, but the characters of alteration zones differ. Király Hill has the widest mineral paragenesis 


\begin{tabular}{|l|lll|}
\hline Layout: T3 Standard Unicode & Book ID: 318043_1_En & Book ISBN: 978-3-319-08996-6 \\
Chapter No.: 26 & Date: 21-11-2014 & Time: 6:57 pm & Page: 5/9 \\
\hline
\end{tabular}

Fig. 26.5 Geological cross-section Cinegés quarry-Király Hill tectonic line (Fig. 26.2) with the main alteration zones (modified after Molnár 1993). 1 Hydrothermal breccia; 2 quartz-opal-barite-cinnabarhematite; 3 quartz-opal-alunitekaolinite; 4 quartz-opal-kaolinite; 5 montmorillonite-illite-kaolinite; 6 illite-kaolinite-montmorillonite; 7 adularia-illite-hematite; 8 Sárospatak boreholes. The millstone quarry was deepened in alteration zone 2

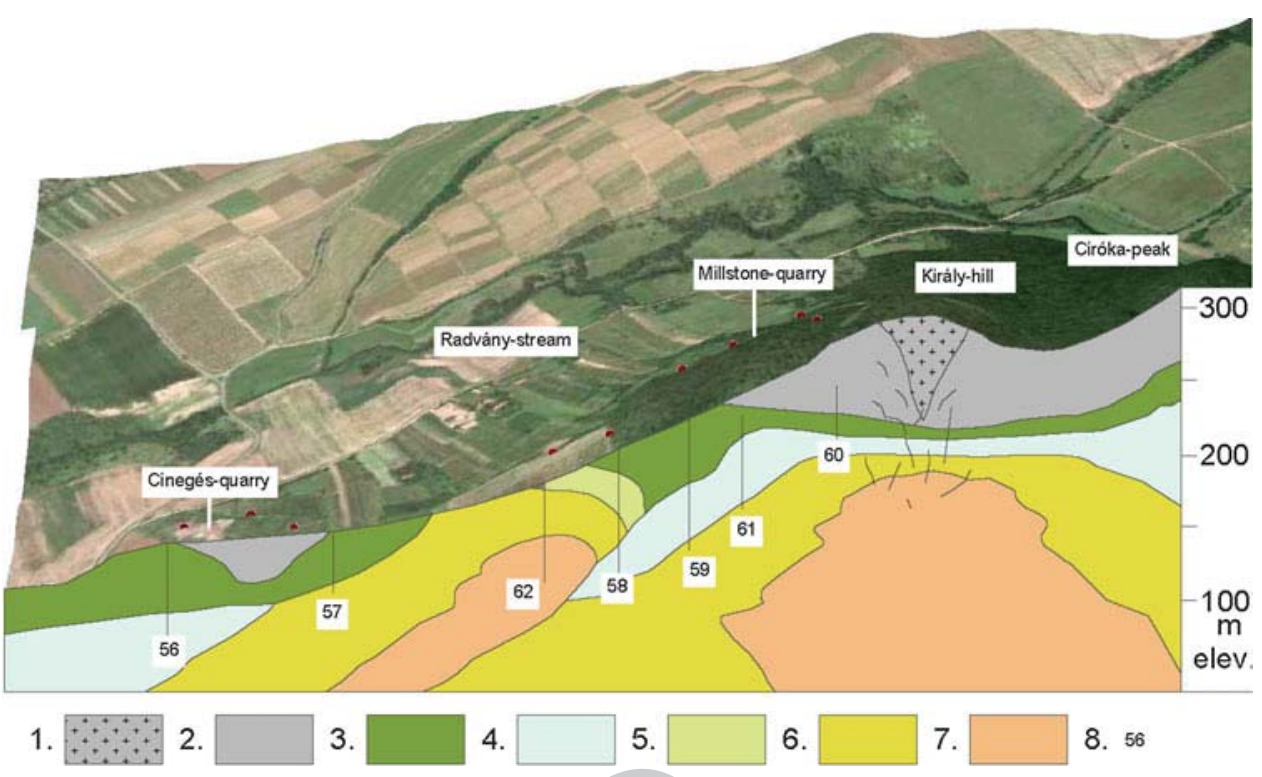

(Fig. 26.5). The first stage of the postvolcanic alteration probably was simultaneous with acid volcanism. Areal silicification affected almost the whole region and represents the sites of highest temperatures and strongest fluid exchange and leaching processes. The most silicified rocks formed along faults and fractures acted as conduits for hyrothermal fluids. The large proportion of the pumices dissolved with changing of hardness. Strongly silicified rock bodies cap Király Hill, Megyer Hill, Cinegés and Botkő Hill (Fig. 26.5). The concentration of silica in these rocks is above $95 \%$ and the original tuff texture is totally destroyed, only quartz phenocrysts are observable (Gyarmati and Pentelény 1973; Mátyás 1979) Cinnabar is present as dust-like encrustations in the cavities or dendritic pattern in the silicified rock (Molnár 1993). Sanidine phenocrysts and the groundmass of the tuff are altered to illite and kaolinite (Kulcsár and Barta 1969; Molnár 1993).

With reducing intensity of alteration the siliceous horizons were underlain by alunite and kaolinite alteration zones (Molnár 1993), which were moderately resistant to erosion and are exposed in lower positions (Fig. 26.5). The argillized rock is locally stained red, purple, brown or yellow depending on iron oxide content. Aggregates of fine-grained $(0.1-0.5 \mathrm{~mm})$ rhombohedral alunite crystals occur in the cavities formed by leaching of the pumice fragments of the tuff. Parallel with this the dominant $\mathrm{SiO}_{2}$ mineral changes from quartz to opal and cristobalite. The illite and montmorillonite dominated and a potassic feldspar (adularia) bearing zone alteration zones formed beneath the kaolinitealunite horizon at Király Hill (Molnár 1993) providing a typical low temperature hydrothermal alteration pattern.

\subsection{Mining History of Sárospatak}

The exploitation of rock varieties (rhyolite tuffs and rhyolite, perlite, obsidian lavas) produced by acid volcanism and hydrothermal activity has thousands of years of history. At the different level of social and technical development more and more raw materials were placed in the centre of interest from the early Neolithic obsidians. Rhyolite tuffs show the widest distribution at Tokaj-Hegyalja and have been utilized as a natural building stone for several centuries as demonstrated by large numbers of abandoned quarries (Fig. 26.2). Data on ancient quarries were registered in the early domestic geological mining inventory (Schafarzik 1904) and also in recent databases (Atlas of European Millstone quarries, Historic Quarries, Hungarian Mineral Occurences).

The silicified zones of Megyer Hill were proper for quality millstones. After the first mentioning from the 15 th century quartzite was a popular and precious product over six centuries. The industry was supported by the grindstones demand of precious metal mining at Telkibánya. The quality and spatial awareness of the stones had earned a reputation for Sárospatak.

The regional industrial activity (building stones and millstone) stimulated the development of clay mineral quarrying and ceramic industry, which had a golden age in the 1800 s. Pottery, tile stove and pipe factories ("famous black pipe") were also operated (Mátyás 2005). The large variety of dish forms (bowls, plates, jars, food containers, jugs) was widespread in the villages of Tokaj-Hegyalja, Hegyköz and Bodrogköz. The kaolin resources (Megyer 


\begin{tabular}{|l|lll|}
\hline Layout: T3 Standard Unicode & Book ID: 318043_1_En & Book ISBN: 978-3-319-08996-6 \\
Chapter No.: 26 & Date: 21-11-2014 & Time: 6:57 pm & Page: 6/9 \\
\hline
\end{tabular}

Hill, Végardó) excavated from five quarries in the late 19th century. The most valuable portion of the deposit was the snow-white dense upper parts but bentonitic ("greasy") kaolin was also mined. Unfortunately the production intensively decreased after the world war. The clay minerals and alunite stocks were re-investigated in the 1950-1980 years (Frits 1959, 1964; Mátyás 1977; Perlaki 1989). The Végardó clay deposit was excavated by underground working through a 76-m-deep shaft only between 1957-1959 (Izsó 2011). The kaolin resources of Botkő exploited from 1972, the alunite stocks from 1977. As a result of the raw material inhomogeneity and other risk factors the mining activities had to stop.

\subsection{The Old Quarry of Megyer Hill}

The silicified zones are easily recognized as resistant outcrops over the entire area of Tokaj Hegyalja (Szerencs, Mád, Sárospatak). Megyer Hill forms the eastern side of the arcuate hydrothermally altered range. The geographical position of quartzite deposits has controlled the shape and alignment of present valleys. The downcutting Suta Stream was forced northward by the greater resistance of low quartzite hills (Cinegés and Botkö). The silicified zones are surrounded by argillized rocks. The minor kaolinite reserve of Megyer Hill was mined for the Zsolnay porcelain factory of Pécs between 1887 and 1940 (Boczán et al. 1966).

The old millstone mine was deepened in the silicified cap where the permeable lapilli tuff and tuff breccia wallrocks promoted the hardening process. The quarry operated from 1,400 years and a three-level mine of $150 \times 50 \mathrm{~m}$ was deepened during the 500 years of mining. The lowermost level is the "Óbánya" with the canyon-like narrow wagon road and the picturesque lake (Fig. 26.1). Cold air is accumulating at the bottom of the old quarry pit and a thick ice sheet covers the water in winter and early spring (Fig. 26.1). The vertical quarry walls are up to $70 \mathrm{~m}$ high above the lake. (That is why the lake is popularly called a "tarn".) The second level is situated 5-6 $\mathrm{m}$ above the water level with the mining buildings but the substandard millstones left behind are also characteristic. The third, topmost and widest, level where a two-roomed cave with windows, doors and stove was also carved in stone.

The excavation was carried out with the similar manual technique and toolkit for centuries, as attested by the curvy walls. The main users were grain (wind, water, dry and hand mills) and ore milling industry. Initially whole stones were mined, ca 300-450 pieces a year. First, circles were drawn around on the rock. The grinding surface of stone pairs was made from opposite rocks for the best fitting in the mill. The wheat grains slightly roasted during the milling which gave a pleasant flavour to the flour. The deepening of the quarry yard called for an easier way for transportation and a canyon-like wagon path was cut into the rock (Fig. 26.6). Unfortunately, productivity decreased at the end of 19th century and the Megyer Hill quarry ceased to operate in 1907.

A picturesque lake was formed by rainwater accumulation in the quarry yard. The constant volume of water is ca $4,000 \mathrm{~m}^{3}$ with a maximum depth about $6 \mathrm{~m}$ higher than expected from the annual rainfall. The absent of evaporation lines also prove that the hydrological cycle is not only climate related and must be an additional inflow along the fractures. The hydrothermal alteration pattern also plays an important role. The argillation zone with clay minerals (kaolinite, illite, monmorrillonite) forms an impermeable layer under the fractured silicified cap.

Beside the mining heritage the area has specific botanical and zoological values. The main plant community is acidophilus oak forest (Genisto tinctoriae-Quercetum), but the mining activity caused continuous degradation. Today, the scrubby-woody vegetation has been reclaiming the quarry

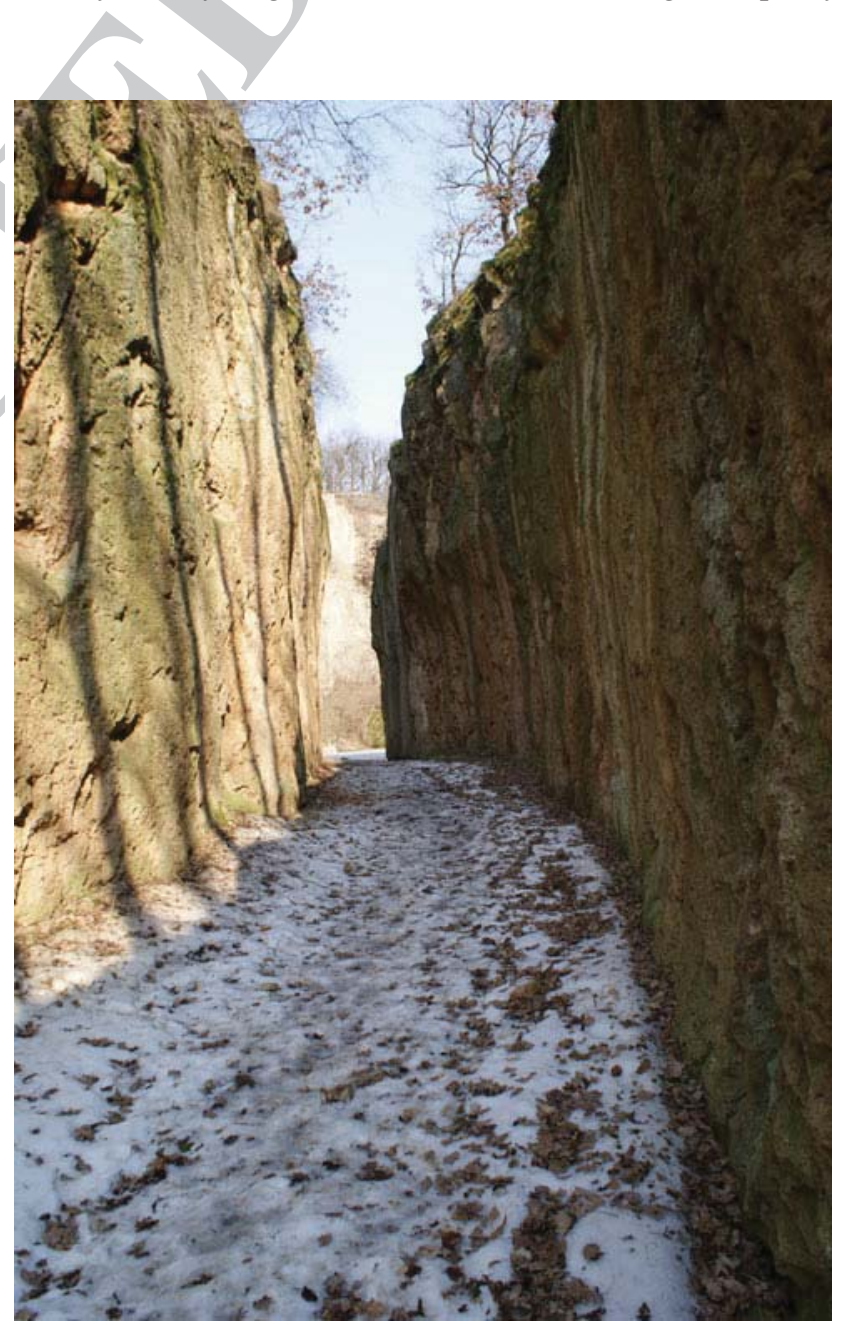

Fig. 26.6 The vertical walls of the wagon road (photo by János Szepesi) 


\begin{tabular}{|l|lll|}
\hline 20 & Layout: T3 Standard Unicode & Book ID: 318043_1_En & Book ISBN: 978-3-319-08996-6 \\
Chapter No.: 26 & Date: 21-11-2014 & Time: 6:57 pm & Page: 7/9 \\
\hline
\end{tabular}

walls and need control for the better visibility. The maple-oak woods (Aceri tatarico-Quercetum)) formerly covered the loess deposited foothill slopes but receded with the spreading of viticulture. Accumulating water promoted the establishment of waterside and aquatic plants. Half of the lake's surface is covered by small duckweed (Lemna minor) and submerged cross duckweed (Lemna trisulca) from spring to fall (Mercsák et al. 2007). Grapes are cultivated on the southern slopes of Megyer Hill for hundreds of years. The plantations are now mostly aged and often abandoned.

The fauna is rich in species despite of small size of the protected area owing to the forests and the favourable exposure of the quarry walls. The lake is important breeding and feeding sites of the amphibian species (frogs), but large numbers of singing birds waterfowl and reptiles (lizards, glides) are also specific.

The amazing 1.1 ha quarry yard with area of Megyer Hill was declared a nature reserve in 1977, which became a nature conservation area of national interest in 1997. It would be appropriate to extend the boundary of the protected area to the forests and Király Hill (in south-western direction) in order to maintaining the fauna richness of the natural reserve (Mercsák et al. 2007).

\subsection{World Champion Millstones}

The new chapter of Sárospatak millstone industry has already started in the middle of 19th century. The preparation of the so-called "French-style" millstones has begun in 1859 in the Botkő mine and 1864 in the Király-hill quartzite mine.
French-style millstone manufacturing was based on an increasing number of more efficient power mills at the expense of water, wind and dry mills in the mid-19th century. The faster rotation of these mills needed long-lasting, wearresisting stones from harder rock. The French millstone manufacturing centres (La Ferté sous Jouarre, Margay, Epernon, Vernot, see Atlas of European Millstone quarries) dominated the world market for a long time. French millstone manufacturing in Hungary was born in the Tokaj Mountains. The millstone manufactory was founded at Fony in 1858 and first grinding stone was assembled in Budapest (Haggenmacker power mill). Similar plants started operating in the first half of the 1860s at Rátka and Szegilong, but the largest size and reputation was reached by the plant founded by K. Láczay Szabó at Sárospatak (Fig. 26.2). The production of French millstones from the quartzite of Botkő Hill started in 1859. Initially, French factory workers were also employed, and later worked with locals. The millstones won "first-order medal" at the 1862 World Expo in London and other shows (Prague, Vienna, Szeged, Székesfehérvár) also featured a great success: "the stones have achieved their goals and the French flint stones became unnecessary with breaking their price and sixty people have been employed. 42 millstones have been sold only at region of Trieste, the export reached the border of France, even longer grind in Switzerland" (LáczaySzabó 1864). Additional high-grade material discovered at the Király Hill in 1864, which retained the sharpness through 8-10 days and foremost was suitable for wet grinding.

The production of the French-style millstone required complex activity. The mining was made primarily by hand tools until the 1950 years. The millstones were always done in
Fig. 26.7 Millstone left behind in the quarry yard (photo by János Szepesi)

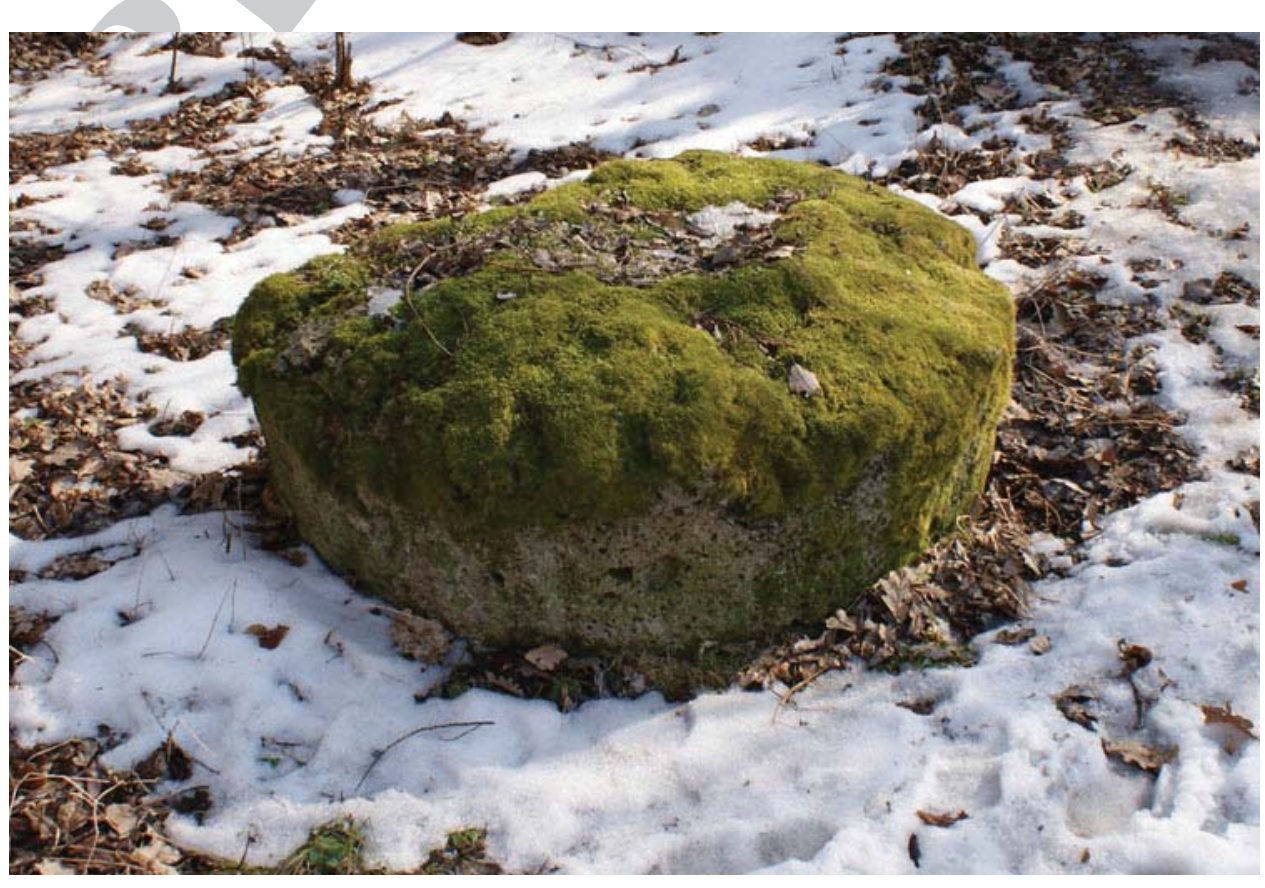




\begin{tabular}{|l|lll|}
\hline Layout: T3 Standard Unicode & Book ID: 318043_1_En & Book ISBN: 978-3-319-08996-6 \\
Chapter No.: 26 & Date: 21-11-2014 & Time: 6:57 pm & Page: 8/9 \\
\hline
\end{tabular}

pairs; one lower stone and a rotating upper block were cut to ensure uniform grinding and abrasion. The selected stones have the same hardness and porosity. The porosity defined two different rock types. The denser variety was suitable for lower stone and the more porous for rotating block. A millstone consisted of two parts: from the inner "heart stone" and the glued, outer "bricks" (12-16 pieces), which defined the French style. The bricks were suited around the "heart" in cement stuck and were left to harden at least 2-3 days. Finally, an iron frame placing around and angled slots were carved out to promote cooling and outward drifting of the grist.

The plant operated successfully in the first decades of the 20th century, although only 200-300 pieces were produced annually contrary to the past 400-500 millstones. The expansion of steel rolling mills heavily influenced manufacturing, but the stones were ordered and delivered even in 1944. The plant was nationalized in the early 1950. The production was about 150 millstones in the 1950-1960 years and 6-10 pieces in the 1970s. Major customers were the paprika mills and the Herend and Pécs porcelain factories. The last millstone was taken in 1979, when excavation in the Király Hill quarry terminated. Some examples are still seen scattered in the yard of the quarry (Fig. 26.7). Afterwards only stone lining of drum mills was made from the Botkö quartzite (Hála 1993).

\subsection{Conclusions}

The landscape around Megyer Hill represents the typical natural and cultural heritage of Tokaj-Hegyalja. The lower slopes are covered by vineyards. The remnants of old volcanism and geysers were revealed by quarrying activity since the 15 th century. The amazing quarry yard of Megyer Hill was declared nature conservation area of national interest in 1997. The main purpose of conservation management is the preservation of geological values and mining history. Specific botanical and zoological values formed by the accumulation of rainwater since the termination of mining activities. About 150 years later of the world champion winning millstones the natural and cultural heritage received another first prize: as Hungary's most beautiful natural attractions in 2011 (www.origo.hu), which underlines the great public interest in the preservation of this natural monument.

\section{References}

Atlas of European Millstone quarries. http://meuliere.ish-lyon.cnrs.fr/ en/Heritage.htm

Historic Quarries. http://www.historic-quarries.org

Hungarian Mineral Occurences. http://www.geomania.org
Boczán B, Franyó F, Frits J, Láng S, Moldvay L, Pantó G, Rónai A. Stefanovits P. (1966): Sátoraljaújhely. Magyarázó Magyarország 200000-es földtani térképsorozatához (Memoir to the geological maps of Hungary, 1:200, 000 series (.) Geological Institute of Hungary, Budapest, pp 1-132 (in Hungarian)

Frits J (1959) A végardói bentonit és kaolin előfordulás (Kaolin and bentonite of Végardó). Annual report of Geological Institute of Hungary for 1955, pp 47-55 (in Hungarian)

Frits J (1964) A végardói termális vonal (The thermal line of Végardó). Annual report of Geological Institute of Hungary for 1961, pp 505-515 (in Hungarian)

Gyarmati P, Pentelény L (1973) Makkoshotyka-Sátoraljaújhely. Magyarázó a Tokaj-hegység földtani térképéhez. 1:25000-es sorozat (Memoir to the geological maps of the Tokaj Mountains, 1:25,000) Geological Institute of Hungary, Budapest, pp 1-39 (in Hungarian)

Gyarmati P (1977) A Tokaji-hegység itermedier vulkanizmusa (Intermedier volcanism of the Tokaj Mountains). Ann Hung Geol Inst 58:1-195 (in Hungarian)

Gyarmati P, Szepesi J (2007): Fejlödéstörténet, földtani felépítés, földtani értékek (History, geology, and geological values) in: Baráz Cs, Kiss G (eds) A Zempléni Tájvédelmi Körzet, Abaúj és Zemplén határán (The Zemplén Landscape Protection Area, at the boundary of Abaúj and Zemplén) Bükk National Park, Eger, pp 15-44 (in Hungarian)

Hála J (1993) A sárospataki "francia malomkő" (French Millstones of Sárospatak). Yearbook of Hermann Otto Museum 30-31(1): 485-511

I. Perlaki E (1989) Sárospatak Király-hegy alunit előfordulása (Alunite occurence of the Sárospatak Király-hill). Annual report of Geological Institute of Hungary for 1965, pp 345-349 (in Hungarian)

Izsó I (2011) A Miskolci Bányakapitányság kerületének bányaipara (Mining industry of Miskolc Mining Station district) p 83 (in Hungarian)

Kulcsár L (1968) A magyar-szovjet határmenti vulkánosság a legújabb szovjet és hazai kutatások tükrében (The volcanism along SovietHungarian border in the light of recent research in Soviet Union and Hungary). Acta Geogr Debrecina 14(7):143-160 (in Hungarian)

Kulcsár L, Barta I (1969) A sárospataki higanyérc kutatással kacsolatos kőzettani és geokémiai vizsgálatok (Petrological and geochemical investigation of mercury ore at Sárospatak) manuscript National Geological Repository 1-95 (in Hungarian)

Mátyás E (1969) Hydrothermal mineral parageneses in some fields of postvolcanic actitvity 9th congress of the Carpatho-Balkan Geological Association 4, pp 400-418

Mátyás E (1977) A Sárospatak-Botkői hidrotermális mező alunitos fáciesterületének földtani és teleptani viszonyai (Economic geology of alunitic zone at the hydrothermal area of Sárospatak-Botkö) manuscript National Geological Repository, pp 1-225

Mátyás E (2005) A Tokaji-hegységi nemfémes ásványi nyersanyagok földtani kutatásának és bányászatának története (The research and mining history of the non-metallic raw materials in the Tokaj Mts.). In: Mátyás E (ed) A Tokaji-hegység geologiája és ásványi nyersanyagai egy geológus életútja tükrében (The geology and raw materials of the Tokaj Mts. in the view of a geologist life), pp 297-362 (in Hungarian)

Mercsák JL, Farkas T, Farkas R, Boldogh S, Huber A, Vrók V (2007) A Megyer-hegyi Tengerszem TT természetvédelmi kezelési terve 2008-2018. (Nature conservation plan of Megyer Hill lake Nature Conservation Area) Aggtelek National Park, pp 1-52

Molnár F (1993) Tokaji-hegységi ércesedések és indikációk genetikája folyadékzárvány vizsgálatok alapján (Genesis of ore deposits and indications of Tokaj Mts. on the basis of fluid inclusion studies). Unpublished $\mathrm{PhD}$ thesis. Eötvös Loránd University, Budapest, pp 1-177 (in Hungarian)

Láczay-Szabó K (1864) A sárospataki kova malomkőgyártásnak legújabb, megbecsülhetetlen vívmányai (The latest precious 


\begin{tabular}{|l|lll|}
\hline 2 & Layout: T3 Standard Unicode & Book ID: 318043_1_En & Book ISBN: 978-3-319-08996-6 \\
Chapter No.: 26 & Date: 21-11-2014 & Time: 6:57 pm & Page: 9/9 \\
\hline
\end{tabular}

achievement of the Sárospatak millstone manufactory) Pesti Napló 15(268):2 (in Hungarian)

Pécskay Z, Lexa J, Szakács A, Balogh K, Seghedi I, Konecný V, Kovác M, Márton E, Széky-Fux V, Póka T, Gyarmati P, Edelstein O, Rosu $\mathrm{E}, \mathrm{Zec}$ B (1995) Space and time distribution of Neogene-quaternary volcanism in the Carpatho-Pannonian region. Acta Volcanologica 72:15-29

Pécskay Z, Molnár F (2002) Relationships between volcanism and hidrothermal activity in the Tokaj Mountains, Northeast Hungary. Geol Carpath Bratislava 53:303-314
Schafarzik F (1904) A magyar korona országai területén létező kőbányák részletes ismertetése (Detailed review of the existing quarries in the countries of the Hungarian Crown). Geological Institute of Hungary, Budapest

Szabó J (1867) Tokaj-Hegyalja és környékének földtani viszonyai (Geology of Tokaj-Hegyalja and its environs). Mathematikai és Természettudományi Közlemények 4:226-303 (in Hungarian). http://www.origo.hu/utazas/20110201-megvan-az-orszag-hettermeszeti-csodaja.html 


\section{Author Query Form}

Book ID : 318043_1_En

Chapter No.: $\mathbf{2 6}$
Springer

the language of science

Please ensure you fill out your response to the queries raised below and return this form along with your corrections

Dear Author

During the process of typesetting your chapter, the following queries have arisen. Please check your typeset proof carefully against the queries listed below and mark the necessary changes either directly on the proof/online grid or in the 'Author's response' area provided below

\begin{tabular}{|l|l|r|}
\hline Query Refs. & Details Required & Author's Response \\
\hline AQ1 & $\begin{array}{l}\text { The citation 'Szabó (1866)' has been changed to 'Szabó (1867)' so that this citation matches the list. please check and confirm. } \\
\text { AQ2 }\end{array}$ & $\begin{array}{l}\text { Reference 'Mátyás 1979' is cited in the text but not provided in the reference list. Please provide the respective reference in the list } \\
\text { or delete this citation. }\end{array}$ \\
\hline
\end{tabular}




\section{Please correct and return this set}

Please use the proof correction marks shown below for all alterations and corrections. If you wish to return your proof by fax you should ensure that all amendments are written clearly in dark ink and are made well within the page margins.

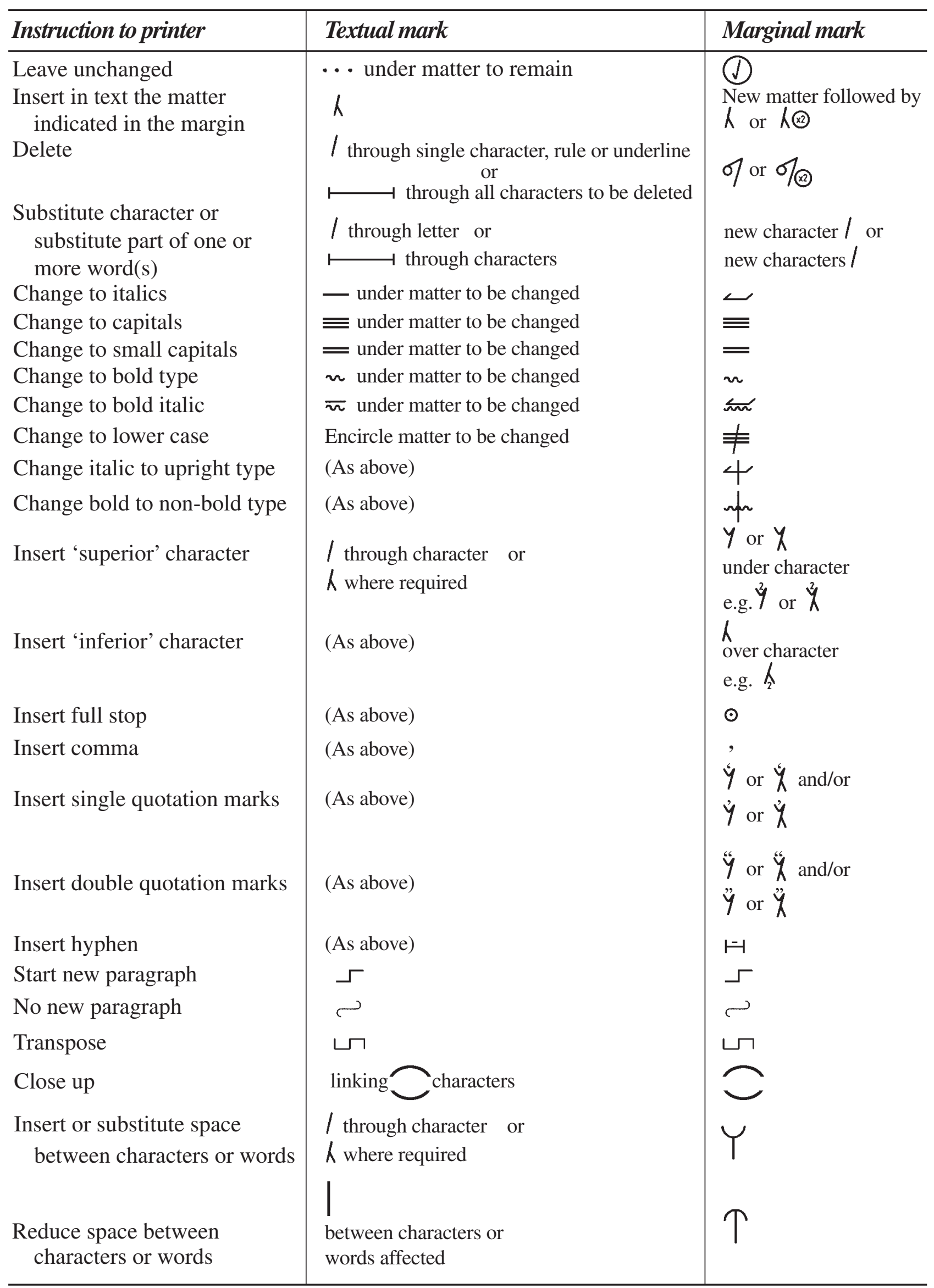

